\title{
Increased leptin concentration in preterm infants of pre-eclamptic mothers
}

\author{
Timo Hytinantti, Heikki A Koistinen, Veikko A Koivisto, Sirkka-Liisa Karonen, \\ Eeva-Marja Rutanen, Sture Andersson
}

leptin concentrations was observed by others. ${ }^{8}$ In pre-eclampsia, maternal plasma leptin concentrations are increased, possibly because of placental production of the hormone under hypoxic conditions. ${ }^{13}$ The effects of preeclampsia on fetal concentrations of leptin are not known.

Given the putative role of leptin as a regulator of fetal development, it is important to identify factors regulating leptin metabolism in utero. ${ }^{14}$ In the present study, we measured leptin concentrations in cord plasma of 74 small preterm infants, gestational age below 32 weeks, to find out which factors are associated with leptin levels. Specifically, we examined whether leptin concentrations are associated with gestational age and birth weight of the infant, and whether maternal pre-eclampsia results in altered leptin levels in preterm infants.

\section{Patients and methods}

PATIENTS

We studied 74 preterm infants, born from consecutive preterm deliveries in the Department of Obstetrics and Gynaecology of Helsinki University Central Hospital, at gestational age 24.1-32 weeks and birth weight 385-2100 g (table 1). The upper limit of gestational age was chosen to minimise the effect of accumulating fetal fat mass as a source of leptin. ${ }^{15}$ Gestational age was determined by ultrasound during the first trimester. Relative birth weight (weight SD) was determined by reference to a Finnish newborn population of 74766 singeltons born in 1978-1982. ${ }^{16}$ Fourteen of the infants were born to mothers who had established proteinuric pre-eclampsia (table 2). IUGR (weight $<-2 \mathrm{SD}$ ) was present in 10 infants (table 2); of the infants with IUGR, five were born to pre-eclamptic mothers and two each from two triplet pregnancies without preeclampsia. Four pairs of twins and six infants from triplet pregnancies were included in the study. In 59 cases the mother had received antenatal treatment with corticosteroids, in the form of two doses of $12 \mathrm{mg}$ betamethasone with a 12 hour interval, more than 12 hours before delivery (mean four days seven hours, SD three days 17 hours, range 12 hours to 16 days) (table 2). Body mass index (BMI) was determined as weight $(\mathrm{kg}) /$ length $(\mathrm{m})^{2}$. Of the infants studied, 32 were delivered vaginally and 42 by caesarean section. Twelve mothers smoked at least five cigarettes a day. Infants of diabetic mothers and infants with malformations were excluded. 
Table 1 Data on 74 preterm infants

\begin{tabular}{ll}
\hline Male/female & $37 / 37$ \\
Gestational age (weeks) & $28.7(2.4)$ \\
Weight $(\mathrm{g})$ & $1180(396)$ \\
Length $(\mathrm{cm})$ & $37.5(4.0)$ \\
BMI $\left(\mathrm{kg} / \mathrm{m}^{2}\right)$ & $8.5(1.3)$ \\
Placenta $(\mathrm{g})$ & $451(180)$ \\
\hline
\end{tabular}

Where applicable, values are mean (SD).

BMI, body mass index.

METHODS

Blood samples from the umbilical vein were taken at birth into EDTA tubes. The tubes were centrifuged at $1000 \mathrm{~g}$ for five minutes, and plasma was stored at $-20^{\circ} \mathrm{C}$ until analysis. Leptin was determined by radioimmunoassay (Linco Research, St Charles, Missouri, USA). ${ }^{17}$ The detection limit of this assay is $0.26 \mu \mathrm{g} / \mathrm{l}$ in our laboratory as determined by calculating 2 standard deviations (mean of 13 assays) from the zero reference point, and the intra-assay and interassay coefficients of variation at low concentration $(2.8 \mu \mathrm{g} / \mathrm{l})$ are $4.7 \%$ and $2.6 \%$ and at medium concentration $(15.6 \mu \mathrm{g} / \mathrm{l}) 3.8 \%$ and $2.2 \%$ respectively.

\section{STATISTICAL ANALYSIS}

Comparisons between grouped items were performed using an unpaired $t$ test. Grouped items (pre-eclampsia, antenatal steroids, smoking, etc) were categorised as either no $=0$ or yes $=1$. Leptin concentrations were logarithmically transformed to normalise the distribution. Simple and multiple regression analysis were used. $p<0.05$ was considered statistically significant. The results are given as mean (SD) and as median and interquartile range. All calculations were carried out with StatView 4.1 (Abacus Concepts Inc, Berkeley, California, USA).

ETHICS

The study was approved by the ethics committee of the Department of Obstetrics and Gynaecology, Helsinki University Central Hospital.

\section{Results}

Immunoreactive leptin was detectable in cord plasma samples from all preterm infants. Median leptin concentration was 1.01 (interquartile range $0.81-1.43) \mu \mathrm{g} / \mathrm{l}$. A significant correlation was found between cord blood leptin and gestational age $(r=0.336, \mathrm{p}=0.0037)$, but not with birth weight $(r=0.155)$, relative birth weight $(r=0.211)$, BMI $(r=0.186)$, placental weight $(r=-0.108)$, Apgar score $(r=0.197)$, or cord artery $\mathrm{pH}(r=-0.104)$.

Significantly higher leptin levels were found in infants of pre-eclamptic mothers (median $1.80(1.11-2.08) v$ median 0.93 (0.79-1.29) $\mu \mathrm{g} / \mathrm{l} ; \quad \mathrm{p}=0.0007)$, in infants with IUGR (median $1.80(1.34-3.04) v$ median 0.93 $(0.74-1.03) \mu \mathrm{g} / 1 ; \mathrm{p}=0.0005)$ and in those exposed to antenatal steroids (median 1.18 $(0.85-1.73) v$ median $0.76(0.66-0.95) \mu \mathrm{g} / 1$; $\mathrm{p}=0.02)$. Maternal smoking was not observed to affect cord blood leptin concentrations. Infants of pre-eclamptic mothers had significantly smaller placentas than other infants (322 (118) v 451 (180) g; $\mathrm{p}<0.05)$.

When gestational age, presence of preeclampsia, and exposure to antenatal steroids were included as independent determinants of leptin concentration in multiple regression analysis, gestational age (partial $r=0.257$, $\mathrm{p}=0.02$ ) and pre-eclampsia (partial $r=0.32$, $\mathrm{p}=0.004$ ) were significantly and independently associated with leptin, whereas exposure to steroids remained non-significant (partial $r=0.103, \mathrm{p}=0.39$ ).

When infants with IUGR and infants born to pre-eclamptic mothers were excluded, simple regression analysis of the 55 remaining infants showed significant correlations between cord leptin levels and gestational age $(r=0.360$, $\mathrm{p}=0.0069)$, BMI $(r=0.424, \mathrm{p}=0.0033)$, and birth weight $(r=0.487, \mathrm{p}=0.0002)$. In these 55 infants, cord plasma leptin concentration of those exposed to antenatal steroids $(\mathrm{n}=41)$ did not differ from those not exposed (median $0.94(0.81-1.30) \quad v$ median 0.75 $(0.65-0.86) \mu \mathrm{g} / \mathrm{l}, \mathrm{p}=0.09)$.

\section{Discussion}

Our data show that, in preterm infants, maternal pre-eclampsia is associated with increased leptin concentration and that pre-eclampsia is an independent determinant of leptin levels. Pre-eclampsia has recently been shown to increase maternal leptin levels, but no such association has yet been reported in the fetus. ${ }^{13}$ Reduced uteroplacental blood flow leading to fetoplacental hypoxia is important in the pathogenesis of IUGR - for example, in pre-eclampsia. ${ }^{18}$ Mise et $a l^{13}$ postulate that elevated maternal plasma leptin concentration in pre-eclampsia is caused mostly by the augmentation of placental production of leptin in response to hypoxia. However, in our study,

Table 2 Infants with and without maternal pre-eclampsia, intrauterine growth retardation (IUGR), and exposure to betamethasone

\begin{tabular}{|c|c|c|c|c|c|c|}
\hline & \multicolumn{2}{|l|}{ Pre-eclampsia } & \multicolumn{2}{|l|}{$I U G R$} & \multicolumn{2}{|c|}{ Betamethasone } \\
\hline & Yes $(n=14)$ & No $(n=60)$ & Yes $(n=10)$ & No $(n=64)$ & Yes $(n=59)$ & No $(n=15)$ \\
\hline Male/female & $10 / 4$ & $27 / 33$ & $5 / 5$ & $32 / 32$ & $29 / 30$ & $8 / 7$ \\
\hline Gestational age (weeks) & $29.4(1.5)$ & $28.5(2.5)$ & $29.6(2.6)$ & $28.5(2.3)$ & $29.1(2.1) \ddagger$ & $27.0(2.7)$ \\
\hline Weight (g) & $1048(221)$ & $1211(421)$ & $940(367) \dagger$ & $1218(389)$ & $1211(379)$ & $1060(450)$ \\
\hline Length $(\mathrm{cm})$ & $36.5(2.5)$ & $37.5(3.9)$ & $36.0(4.0)$ & $37.5(3.7)$ & $38.0(3.5) \ddagger$ & $35.0(4.0)$ \\
\hline BMI $\left(\mathrm{kg} / \mathrm{m}^{2}\right)$ & $7.7(0.4)^{\star}$ & $8.6(1.4)$ & $7.2(0.7) \dagger$ & $8.6(1.3)$ & $8.7(1.2) \ddagger$ & $7.7(1.4)$ \\
\hline Placenta (g) & $322(118)^{\star}$ & $481(179)$ & $358(157)$ & $465(180)$ & $456(191)$ & $429(130)$ \\
\hline
\end{tabular}

Where applicable, values are mean (SD).

${ }^{\star} \mathrm{p}<0.05 v$ infants without maternal pre-eclampsia; $\mathrm{tp}<0.05 v$ infants without IUGR; $\neq \mathrm{p}<0.05 v$ infants without exposure to antenatal steroids.

BMI, body mass index. 
there was no correlation between cord plasma leptin concentration and Apgar score or cord artery $\mathrm{pH}$. In accordance with this, in vitro data indicate that a significant increase in leptin secretion does not occur until 72 hours of hypoxia. ${ }^{13}$

In our study, preterm infants with IUGR, with or without pre-eclampsia, had higher cord leptin levels than those with normal growth. This is in contrast with that observed in most, but not all, studies on full term infants. $^{9-12}$ Interestingly, in our study, when infants with IUGR and infants of preeclamptic mothers are excluded from the analysis, there is a correlation between birth weight and leptin concentration similar to that observed in term infants. Thus, it is possible that pre-eclampsia, IUGR, and the concomitant increase in leptin concentration may interfere with the association between leptin and birth weight. The overlap between groups of infants with IUGR and maternal preeclampsia makes it difficult to differentiate the effects of these two clinical conditions on leptin metabolism. Our finding of preterm infants with IUGR having higher leptin concentrations agrees with the study of Shekhawat et al, ${ }^{12}$ whereas no such relation was found in a study by Jaquet et al. ${ }^{8}$ However, the possible connection of pre-eclampsia with fetal leptin concentrations was not examined in those studies. ${ }^{8}{ }^{12}$ Moreover, in term infants, maturity and fetal fat mass may interfere with the effects of preeclampsia on fetal leptin.

In this study, the weight of the placenta did not correlate with leptin concentration as in term infants. ${ }^{9}$ In fact, infants of pre-eclamptic mothers had smaller placentas and increased leptin concentration. This finding may be explained by the hypothesis that hypoxia augments placental production of leptin. ${ }^{13}$

Hypoxia and IUGR, the fetal hallmarks of pre-eclampsia, are associated with increased morbidity. ${ }^{18}{ }^{19}$ The roles of leptin in haematopoiesis, fetal erythroid development, and angiogenesis raise the possibility that relative hyperleptinaemia is a part of the fetal adaptation to hypoxia. ${ }^{50-22}$ In adults, plasma leptin levels are increased in survivors of acute sepsis, and leptin has been claimed to be a stress related hormone. ${ }^{23}$ Thus it may also play a role in response to severe stress states in the fetus, such as pre-eclampsia.

Shekhawat and co-workers ${ }^{12}$ found that the use of antenatal steroids was associated with increased cord plasma leptin levels in preterm infants. The mean gestational age in their study was 32 weeks, and infants of diabetic mothers were included. Unfortunately, no weight data were available on the infants exposed to antenatal steroids, making the interpretation of their results difficult. In our infants, we also found an association between the use of antenatal steroids and high cord plasma leptin. However, this correlation disappeared when infants with IUGR and infants born to mothers with pre-eclampsia were excluded. Moreover, in multiple regression analysis, antenatal exposure to steroids was not an independent determinant of leptin lev- els. Therefore it is possible that the effect of antenatal steroids on leptin production is primarily dependent on maturity. So far, in adults also the effects of corticosteroids on leptin levels are disputed. ${ }^{24} 25$

We found that maturity, defined by gestational age, is a significant determinant of cord plasma leptin levels in preterm infants. This is in accordance with previous studies performed in preterm and term infants. ${ }^{8-12}$ This may be related to the accumulation of adipose tissue in the fetus during late gestation. ${ }^{15}$ Given the presence of mRNA for leptin receptor isoforms in the lung, liver, kidneys, and haematopoietic cell lines of human fetuses, these data suggest that leptin may participate in the regulation of fetal growth and development.

In conclusion, gestational age is an important determinant of cord plasma leptin levels in preterm infants. Leptin levels are increased in pre-eclampsia and IUGR, which may be part of the physiological adaptation to stress during the fetal period.

The excellent technical assistance of Ms E Koivisto and Ms T Kyösti-Renvall is appreciated. The study was supported by the
Yrjö Jahnsson Foundation, the Finnish Academy of Science, the Finnish Medical Foundation, Paulo Foundation, Novo Nordisk Foundation, the Research Foundation of Orion Corporation, and Finska Läkaresällskapet.

1 Zhang Y, Proenca R, Maffei M, Barone M, Leopold L, Friedman JM. Positional cloning of the mouse obese gene and its human homologue. Nature 1994;372:425-32.

2 Pelleymounter MA, Cullen MJ, Baker MB, et al. Effects of the obese gene product on body weight regulation in ob/ob mice. Science 1995;269:540-3.

3 Halaas JL, Gajiwala KS, Maffei M, et al. Weight-reducing effects of the plasma protein encoded by the obese gene. Science 1995;269:543-6.

4 Campfield LA, Smith FJ, Guisez Y, Devos R, Burn P. Recombinant mouse OB protein: evidence for a peripheral Recombinant mouse OB protein: evidence for a peripheral
signal linking adiposity and central neural networks. signal linking adiposity
Science 1995;269:546-9.

5 Cioffi JA, Shafer AW, Zupancic TJ, et al. Novel B219/OB receptor isoforms: possible role of leptin in hematopoiesis and reproduction. Nat Med 1996;2:585-8

6 Tartaglia LA. The leptin receptor. I Biol Chem 1997;272:6093-6.

7 Hoggard N, Hunter L, Duncan JS, Williams LM, Trayhurn P, Mercer JG. Leptin and leptin receptor mRNA and protein expression in the murine fetus and placenta. Proc Natl Acad Sci USA 1997;94:11073-8.

8 Jaquet D, Leger J, Levy-Marchal C, Oury JF, Czernichow P. Ontogeny of leptin in human fetuses and newborns: effect Of ogen of leptin in human fetuses and newborns: effect con intrauterine

9 Koistinen HA, Koivisto VA, Andersson S, et al. Leptin concentration in cord blood correlates with intrauterin growth. F Clin Endocrinol Metab 1997;82:3328-30.

10 Harigaya A, Nagashima K, Nako Y, Morikawa A. Relationship between concentration of serum leptin and fetal growth. F Clin Endocrinol Metab 1997;82:3281-4.

11 Tamura T, Goldenberg RL, Johnston KE, Cliver SP. Serum leptin concentrations during pregnancy and their relationship to fetal growth. F Obstet Gynecol 1998:91:389-95.

12 Shekhawat PS, Garland JS, Shivpuri C, et al. Neonatal cord blood leptin: its relationship to birth weight, body mass index, maternal diabetes and steroids. Pediatr Res 1998;43:338-43.

13 Mise H, Sagawa N, Matsumoto T, et al. Augmented placental production of leptin in preeclampsia: possible involvement of placental hypoxia. f Clin Endocrinol Metab ment of placental

14 Hassink SG, de Lancey E, Sheslow DV, et al. Placental leptin: an important new growth factor in intrauterine and neonatal development? Pediatrics 1997;100:1.

15 Carrera JM, Devesa R, Carrera M. Dynamics of fetal growth. In: Kurjak A, ed. Textbook of perinatal medicine. London: The Parthenon Publishing Group, 1998:1140-7.

16 Pihkala J, Hakala T, Voutilainen P, Raivio K. Uudet suomalaiset sikiön kasvukäyrät. Duodecim 1989;105:1540-6.

$17 \mathrm{Ma} \mathrm{Z}$, Gingerich RL, Santiago JV, Klein S, Smith CH, Landt $M$. Radioimmunoassay of leptin in human plasma. Clin Chem 1996;42:942-6.

18 Redman CWG. Current topic: preeclampsia and the placenta. Placenta 1991;12:301-8.

19 Kelly T, Moore TR. Maternal medical disorders of fetal significance: seizure disorders, hypertension and isoimmuni- 
zation. In: Taeusch HW, Ballard RA, eds. Avery's diseases of the newuborn. Philadelphia: WB Saunders, 1998:78-82. 20 Sierrra-Honigmann MR, Nath AK, Murakami C, et al. Biological action of leptin as an angiogenic factor. Science 1998;281:1683-6.

21 Mikhail AA, Beck EX, Shafer A, et al. Leptin stimulates fetal and adult erythroid and myeloid developent. Blood 1997;89:1507-12.

22 Umemoto Y, Tsuji K, Yang FC, Ebihara Y, Kaneko A, Furukawa S, Nakahata T. Leptin stimulates the proliferation of murine myelocytic and primitive hematopoietic progenitor cells. Blood 1997;90:3438-43.
23 Bornstein SR, Licinio J, Tauchnitz R, et al. Plasma leptin levels are increased in survivors of acute sepsis: associated loss of diurnal rhythm in cortisol and leptin secretion. $f$ Clin Endocrinol Metab 1998;83:280-3.

24 Kolaczynski JW, Goldstein BJ, Considine RV. Dexamethasone, OB gene, and leptin in humans; effect of exogenous hyperinsulinemia. F Clin Endocrinol Metab 1997;82:3895-

Trophy DJ, Bornstein SR, Cizza G, Chrousos GP. The effects of glucocorticoids on leptin levels in humans may be restricted to acute pharmacologic dosing. 7 Clin Endocrinol Metab 1998;83:1821-2.

\section{Neonatal jaundice in antiquity}

Since antiquity, jaundice was considered by Jewish sages, as can be seen from their discussions in the Talmud on the Biblical commandment to circumcise every male Jewish infant at 8 days of age, provided that he is medically fit. They were very concerned about jaundice. Today it is recognised that considerably elevated plasma bilirubin levels can have toxic effects on the brain, as well as other organs, and raised levels may indicate septicaemia, urinary infection, or hepatitis.

"Yerakon" is the classical Hebrew word for jaundice in newborn infants. In the Talmud's commentaries, it is suggested that the word is derived from "yarok" which means green in Aramaic but can also be translated as yellow or pallor in both humans and vegetables. In the warnings on punishment for sin in Deuteronomy, "yerakon" (or yellow blight) is one among several punishments that afflict man.

In the Greek translation of the Bible (the Septuagint), written in Alexandria in the 2nd and 3rd centuries BC, the word "yerakon" has been written as "ochre" and sometimes as "ikterus". In the Vulgate Latin translation can be found the term "aerugo" which means the colour of gold, and in modern Hebrew it is called "zahavit" from "zahav" which means gold. In modern Arabic, it is called "warrak", equivalent to the Hebrew term "yarok".

Circumcision is among the oldest surgical procedures practised by Jews and Moslems for religious reasons. Moses Maimonoides (1138-1204) and Joseph Caro (1488-1575) codified the procedure of circumcision based on the Talmudic ruling. It was established that under normal conditions the operation was performed on the eighth day of life, but was postponed until full recovery if there was any evidence of illness, such as jaundice.

ABRAHAO BEREZIN MURILO MELO 